\title{
Octavio Paz y el Surrealismo
}

\author{
Klaus Meyer-Minnemann \\ Universität Hamburg \\ k.i.meyer-minnemann@t-online.de
}

\begin{abstract}
Resumen: La aproximación de Octavio Paz al Surrealismo, la que, después de un primer rechazo total, empieza a manifestarse en el poemario Libertad bajo palabra, de 1949, es bien sabida. Esta aproximación, que por un momento se convierte en adhesión al grupo parisino de André Breton, llega a un punto culminante con la publicación del ensayo "El surrealismo" en Las peras del olmo, de 1957. El presente trabajo se propone esclarecer las características tanto ideológicas como teórico-literarias de esta aproximación en el pensamiento de Paz sobre la base de los conceptos de libertad, amor y poesía, los que Paz hace suyos, recurriendo al ensayo Arcano 17 de Breton. No obstante, la aproximación de Paz al Surrealismo no se da sin algunas reservas, de las cuales destacan la crítica de la exaltación de la figura del marqués de Sade y de la concepción de la escritura automática, en la cual Paz advierte una destrucción de la instancia del yo poético que haría obsoleto el ejercicio de la actividad poética.
\end{abstract}

Palabras clave: Octavio Paz; aproximación al Surrealismo; libertad, amor, poesía; marqués de Sade, escritura automática.

AвsтRACT: The approach of Octavio Paz to Surrealism, which initially after a total disapproval becomes evident in the book of poems of Libertad bajo palabra from 1949, is well known. This approach, turning for a moment into an adherence to the group of André Breton in Paris, culminates in the publication of the essay "El surrealismo" in Las peras del olmo from 1957. The present article aims to illuminate the ideological as well as theoretical-literary characteristics of this approach in the thinking of Paz on the ground of the concepts of freedom, love and poetry, which Paz adopts from the essay Arcane 17 by Breton. However, the approach to Surrealism by Paz does not take place without some reticence, which can be seen clearly in the criticism of the exaltation of the person of the Marquis de Sade and the concept of automatic writing, in which Paz recognizes a destruction of the idea of the poetic self, capable to make the practice of poetic activity obsolete.

KeYwords: Octavio Paz; approach to Surrealism; freedom, love, poetry; Marquis de Sade; automatic writing.

Fecha de Recepción: 4 de enero de 2016.

Fecha de aCeptación: 8 de marzo de 2016. 
$\mathrm{F}^{\mathrm{n}}$ su colección de trabajos de crítica con el título de Las peras del olmo, publicada en México en 1957 bajo el sello de la unAm, Octavio Paz incluye un ensayo que caracteriza su poesía y pensamiento no sólo de aquel momento sino, mutatis mutandis, su obra entera desde la primera edición de Libertad bajo palabra, de 1949. El ensayo, titulado "El surrealismo", fue presentado inicialmente en forma de una conferencia (no se sabe si palabra por palabra), en el marco de un ciclo, organizado por la UNAM en 1954 bajo el lema de "Los grandes temas de nuestro tiempo" (1957: 163-181). La elección del Surrealismo por Paz como tema de su conferencia fue nada menos que un desafío hacia una opinión firmemente arraigada en los medios intelectuales no solamente de México. En aquellos años, el Surrealismo era un movimiento de vanguardia del tiempo de entreguerras, un movimiento considerado pasado de moda y largamente superado por la evolución posterior de las artes y las letras, como el existencialismo francés o el neorrealismo literario y cinematográfico. Elegirlo como uno de los grandes temas del tiempo - si no el gran tema - significaba ir en contra de una opinión generalizada, y, literalmente, pedir peras al olmo. ${ }^{1}$ Además, al presentar al Surrealismo como "una actitud del espíritu humano. Acaso la más antigua y constante, la más poderosa y secreta” (1957: 165), el autor trataba de exceptuarlo de lo que más tarde, en el prólogo a la antología Poesía en movimiento. México 1915-1966, iría a conceptualizar como "la tradición de la ruptura” (1966: 5 ss.) inherente a partir del Romanticismo a todos los movimientos artísticos, los que solían plantearse como avanzada respecto de las tendencias anteriores, pretendiendo superarlas en sus objetivos o, incluso, anular, antes de ser superados o anulados a su vez por otros movimientos más nuevos. ${ }^{2}$

${ }^{1}$ Jean-Paul Sartre, uno de los intelectuales más influyentes de la época, había sustentado una crítica maliciosa y, en parte, feroz, del Surrealismo en su célebre ensayo ¿Qué es la literatura? (versión original en Situations, II. Qu'est-ce que la littérature?) de 1948 (ver Sartre 1968: 214 ss., así como la importante nota 6: 317 ss.). El ensayo ha conocido numerosas traducciones y reimpresiones hasta la actualidad. La crítica del Surrealismo de Sartre ya se había hecho pública, empero aún sin las anotaciones, en una serie de artículos en su revista Les Temps Modernes, números 17 (febrero) a 22 (julio) de 1947 (ver Contat/Rybalka 1970: entrada 47/125).

${ }^{2}$ En Los hijos de limo (1974), Paz construirá toda la historia de la poesía moderna de Occidente alrededor del concepto de "la tradición de la ruptura". Acerca del valor operacional ambiguo de este concepto para la historiografía de la literatura, el que ha gozado de un cierto favor por parte la critica, ver las reflexiones de Vital 1998. En rea- 
Es así como el tema del Surrealismo planteado por Paz entre 1954 y 1957 no sólo fue una tentativa de revitalización de una vanguardia juzgada obsoleta - aunque también fuera eso- sino la presentación del movimiento de Breton y sus compañeros de armas como una manifestación atemporal, no afectada por el devenir histórico. En la caracterización del Surrealismo, Paz recurre a una descripción hecha por Breton en su ensayo Arcano 17 (título original Arcane 17) de 1944. Dice Paz:

En Arcano 17, André Breton habla de una estrella que hace palidecer a las otras: el lucero de la mañana, Lucifer, ángel de la rebelión. Su luz la forman tres elementos: la libertad, el amor y la poesía. Cada uno de ellos se refleja en los otros dos, como tres astros que cruzan sus rayos para formar una estrella única. Así, hablar de la libertad será hablar de la poesía y del amor. Movimiento de rebelión total, nacido del nihilismo dadaista de la primera post-guerra, el surrealismo se proclama como una actividad destructora que quiere hacer tabla rasa con los valores de la civilización racionalista y cristiana. A diferencia del dadaísmo, es también una empresa revolucionaria que aspira a transformar la realidad y, así, obligarla a ser ella misma. Pero el surrealismo no parte de una teoría de la realidad; tampoco es una doctrina de la libertad. Se trata más bien del ejercicio concreto de la libertad, esto es, de poner en acción la libre disposición del hombre en un cuerpo a cuerpo con lo real. Desde el principio la concepción surrealista no distingue entre el conocimiento poético de la realidad y su transformación: conocer es un acto que transforma aquello que se conoce. La actividad poética vuelve a ser una operación mágica (1957: 165 ss.).

Este pasaje es revelador. Resume en unas pocas palabras la visión que Paz tenía del Surrealismo en el momento de la publicación de su ensayo. Asimismo, permite vincular esta visión con la poesía y el pensamiento ulteriores del autor. En efecto, Paz nunca se desmarcó definitivamente del Surrealismo, aunque en años posteriores atenuó su entusiasmo respecto del movimiento de Breton, el que aún emana del ensayo pu-

lidad, el concepto de "la tradición de la ruptura" de Paz remonta, en última instancia, a los formalistas rusos y su conceptualización de la historia literaria como un movimiento continuo entre automatización y extrańamiento. Paz determina el significado de este movimiento para la poesía moderna de Occidente desde el Romanticismo alemán e inglés, alrededor de 1800, hasta el ocaso de la vanguardia en la segunda mitad del siglo xx. 
blicado en Las peras del olmo. Tampoco volvió mucho sobre su ensayo, con excepción de algunos cambios de cierto interés para la evolución de su pensamiento. Sólo el título experimentó una importante variación. Iba a llamarse en las Obras completas, edición del autor, "Estrella de tres puntas: el surrealismo" (2000a: 171-187). ${ }^{3}$ Estas puntas son la libertad, el amor y la poesía. Por lo demás, los cambios introducidos en el ensayo por Paz hasta la versión definitiva no pueden asombrar demasiado. Son el resultado tanto de un afán muy del autor por encontrar la expresión exacta (el mot juste), como de rendir testimonio del desarrollo de su pensamiento. ${ }^{4}$

Veamos ahora un poco más de cerca la tríada con la que Paz caracteriza al Surrealismo. ${ }^{5}$ Paz dice que Breton "habla de una estrella que hace palidecer a las otras: el lucero de la mañana, Lucifer, ángel de la rebelión". Después agrega: "Su luz la forman tres elementos: la libertad, el amor y la poesía". Efectivamente, al final de su ensayo Arcane 17 (publicado en 1944, en Nueva York y, "enté d'ajours", esto es, "injerto de iluminaciones", otra vez en París, en 1947, con múltiples reediciones sucesivas) Breton habla, remitiéndose a La fin de Satan (El fin de Satán)

${ }^{3}$ A partir de 1988, como se sabe, Paz empieza a trabajar en el proyecto de sus Obras completas, edición del autor. Incluye el ensayo sobre el Surrealismo en Excursiones/Incursiones, volumen II de la primera edición de las Obras completas. El volumen sale en 1991 (ver la advertencia del editor en Paz 2000a: 13). Posteriormente, Paz reordena el contenido del volumen para la edición definitiva en ocho tomos. En el volumen II, que ahora se llama Excursiones/Incursiones (Dominio extranjero); Fundación y disidencia (Dominio hispánico) se incluye también un nuevo ensayo, "André Breton: la niebla y el relámpago", que Paz había publicado en Vuelta, en enero de 1996. Aquí, el autor vuelve a mencionar la estrella de tres puntas del Surrealismo, "como decía el mismo Breton: la poesía, el amor, la libertad” (2000c: 214). Nótese que esta vez se ha transformado la tríada de "la libertad, el amor, la poesía" en "la poesía, el amor, la libertad". Por lo demás, el ensayo sobre el Surrealismo de 1954/1957 es el primero de un total de seis ensayos sobre el tema, agrupados en el volumen bajo el título de "André Breton y el Surrealismo" (2000a: 171-221).

${ }^{4}$ No obstante, cabe mencionar también una interpretación distinta de los frecuentes cambios en los textos de Paz, los cuales refejan un esfuerzo del autor por oponerse a la amenaza de independización de sus escritos, una vez publicados, mediante el recurso del comentario, la rectificación y, a veces, la supresión. Pero este procedimiento tampoco puede resultar privativo o sorprendente, piénsese sólo en los frecuentes cambios, rectificaciones o supresiones que Goethe hizo de sus textos hasta la llamada edición "letzter Hand" (de mano última), es decir, la última edición por él realizada.

${ }^{5}$ Paz menciona la tríada de la libertad, el amor y la poesía del Surrealismo también en una entrevista con el argentino Roberto Vernengo del año de 1953 (2005: 597). 
de Victor Hugo, del ángel Lucifer, el ángel rebelde contra Dios, quien en su caída engendra una estrella que no es otra que Venus, el lucero del alba, cuya luz, según Breton, sólo conoce tres vías: la poesía, la libertad y el amor (Breton 1999: 94 y ss.). Para Breton, la rebeldía, y sólo ella, es creadora de luz - "c'est la révolte même, la révolte seule qui est créatrice de lumière” (94). Y es precisamente esta luz, la que caracteriza la poesía, la libertad y el amor.

Para Breton como para Paz en 1954/1957, la actitud de rebeldía (y su manifestación concreta, la rebelión) es fundamentalmente una actitud moral. ${ }^{6}$ Es el denominador común de la libertad, el amor y la poesía. Ambos autores conciben estos tres conceptos, o, mejor dicho, estas tres actividades elementales, como dirigidas en contra de algo: en el caso de la libertad contra cualquier sumisión (tanto la sumisión a la religión y sus administradores, la (o las) Iglesia(s), como la sumisión a una autoridad política, bajo el lema que fuera, o simplemente a una consigna proveniente de donde sea). En el caso del amor, la rebeldía se declara contra cualquier amansamiento o domesticación de la libre elección de la pasión amorosa. Para la poesía, finalmente, la rebeldía consiste en el rechazo de toda restricción de la expresión de la palabra o — no hay que olvidarlo- de los demás medios de expresión, antes que nada en el dominio de las artes plásticas. Para el Surrealismo, la libertad, el amor y la poesía son vías de conocimiento de la realidad, las que permiten penetrar y transformarla más allá de las explicaciones racionalistas e ideológicas que se le suelen aplicar. "Conocer", dice Paz respecto del Surrealismo, "es un acto [mágico] que transforma aquello que se conoce" (1957: 166), y al mismo tiempo, como es preciso añadir, a quien lo va conociendo. En este sentido, vale repetir lo que Breton se propuso proclamar personalmente en el Congreso Internacional de Escritores para la Defensa de la Cultura de 1935 (y no pudo hacer porque los organizadores del evento no le concedieron la palabra): “'Transformar el mundo' dijo Marx, 'cambiar la vida' dijo Rimbaud: esas dos consignas [mots d'ordre en francés] para nosotros sólo forman una" (1992b: 459). Con el tiempo, esta proclamación de Breton se hizo famosa y encontró la aprobación de Paz, por lo menos en el momento en el cual publicó su ensayo sobre el Surrealismo. Al final de su vida

${ }^{6} \mathrm{Y}$ esto, en el caso del Surrealismo, a pesar de algunas declaraciones de rebeldía como acto destructor gratuito; ver Alquié 1955: 72; además Bürger 1996: 197 ss. 
Paz se pregunta en la pequeña semblanza de Breton, publicada en Vuelta en 1996: "¿debo hablar como un hombre tocado por el surrealismo, la enfermedad poética de nuestro siglo, o simplemente como un amigo suyo? Antes de responder a mi pregunta, oigo una voz. Es la de Elisa Breton [la tercera esposa de Breton, que Paz llegó a tratar con frecuencia], que me dice: las dos cosas son una y la misma" (2000c: 213).

No obstante, es sabido que el acercamiento de Paz al Surrealismo (que se convirtió momentáneamente en adhesión) no fue espontáneo. Cuando en 1940 la revista Romance, una publicación del exilio español en México, fundada después de la Guerra Civil, organiza una encuesta literaria, Paz plantea con respecto a la vieja pregunta acerca de la relación entre arte y mentira la opinión siguiente (en la versión de las Obras completas, edición del autor) referente a las características del movimiento surrealista:

El arte barroco (como el neoclásico, aunque en otro sentido) subraya el elemento expresivo, el elemento lenguaje por una especie de desconfianza en la eficacia de la palabra. La mentira invisible del arte sano se substituye por una mentira que se sabe mentira. Todo el mundo está "en el secreto". El engaño total y trágico se convirtió en engaño virtuoso. $\mathrm{Y}$ a este virtuosismo de la sensualidad fatigada y de la expresión gastada no sucedió una salud sino un frenesí. El romanticismo huye de la lucha que en el arte libran la verdad y la mentira, la experiencia y la palabra. El romanticismo, más que la desconfianza en la razón, es la desconfianza en el lenguaje, y, más que la victoria de los sentimientos, es la derrota de la expresión. El surrealismo no ha hecho más que continuar lo que el romanticismo inició; ahora, abandonado por las "musas moderadoras" — las musas del lenguaje— ha caído en la literatura. Es decir, en un lenguaje hecho de lugares comunes (2005: 214).

Para comprender esta postura negativa es necesario tener en mente que el joven Paz abogaba por un arte de univocidad, o, por lo menos aquí, pretendía hacerlo. La mentira invisible del "arte sano", la que encarna, según el autor, en la artificialidad del artefacto, y, referente a la obra literaria, en su literariedad o ficcionalidad, desplaza, en el caso de una desconfianza hacia la eficacia de los medios expresivos, esto es, de su capacidad de significación transparente, el valor de lo representado desde el plano del contenido al plano de la expresión. De esta manera el artefacto, artístico o literario, ganaría en virtuosismo expresivo lo que 
perdería en claridad. Después, en el Romanticismo, el virtuosismo de la palabra (o de la expresión en general) se habría disuelto, cediendo el lugar a un frenesí. El Surrealismo sólo habría continuado este proceso, convirtiéndose en una literatura o un arte hecho de lugares comunes.

Si se toma en cuenta que una de las aspiraciones del Surrealismo, como de las vanguardias históricas en general, consistía en la superación de la autonomización del arte en la sociedad burguesa en favor de su transformación en práctica vital (Bürger 2009), el juicio del joven Paz no podía ser más demoledor. Con motivo de la reimpresión del texto de la revista Romance en Primeras letras (Paz 1988), Paz redactó un comentario, en el cual se esfuerza por explicar su actitud crítica de aquellos ańos hacia el Surrealismo. Dice que su distanciamiento se nutría de dos fuentes. La primera era la ruptura de los surrealistas con el Partido Comunista a mediados de los años treinta, lo cual, en el marco de las controversias políticas de aquella época, significó la ruptura definitiva con las directivas del Partido Comunista de la Tercera Internacional. Entre los escritores y artistas de izquierda, al menos entre los que aún no se habían desprendido del comunismo de partido (como en México lo harán Victor Serge y Gustav Regler, y en otras circunstancias otros escritores como André Gide, por ejemplo), esta ruptura tildó a los surrealistas de lacayos del fascismo, al igual que Trotski, a favor de quien Breton, además, se había manifestado públicamente. Paz no fue miembro del PC (nunca lo será), pero a finales de los años treinta y principios de los cuarenta aún se encontraba bajo su irradiación poderosa.

La segunda fuente del rechazo del Surrealismo por Paz era de índole estética. Treinta años después de las primeras manifestaciones del movimiento surrealista, éste (como los demás movimientos de la vanguardia) pasaba, como ya se ha dicho, por caduco. La proclamación de un "arte lúcido" por Paz frente a los movimientos artísticos anteriores ("Un arte nuevo será un arte distinto y hasta contrario al de los últimos tiempos. Será — como en Baudelaire, como en Nietzsche- un arte lúcido", había declarado el autor [2005: 214]), tuvo como objetivo el afianzamiento de una vanguardia nueva. ${ }^{7}$ Es así como el joven Paz

\footnotetext{
${ }^{7}$ No obstante, la caracterización de Baudelaire y de Nietzsche como modelos de un "arte lúcido" (¿en su época?) por el Paz de la encuesta de Romance no deja de sorprender. ¿Un arte lúcido? ¿En qué sentido? ¿Por su claridad y novedad respecto del Surrealismo? Y tratándose de autores de la segunda mitad del siglo XIX, por eminentes que parezcan al Paz joven, ¿por qué no Rimbaud (el vidente), o Mallarmé?
} 
reproducía, aún sin darse cuenta, la característica de los movimientos de vanguardia de la primera mitad del siglo, que consistía en reclamar para sí, frente a los demás movimientos, el lugar más avanzado de la evolución artística. Además, en su juicio de 1941, Paz pasó por alto el carácter eminentemente ético-moral del Surrealismo, en cuyas negaciones, como posteriormente él mismo lo reconoció, "palpitó siempre el gran Sí de la poesía, el amor y la libertad” (1988: 405).

La pregunta que respecto de este rechazo se impone es: ¿Cuándo se produjo en el autor mexicano el cambio de la orientación estética y política que esgrime en la revista Romance ${ }^{8}{ }^{8}$ ¿En qué momento empezó a revisar su opinión negativa acerca del Surrealismo? Dar una respuesta exacta a esta pregunta es difícil. Parece que el cambio de orientación, hecho público finalmente por la adhesión temporal al grupo de Breton, se inició en relación a las primeras dudas acerca de lo fundado de la convicción, generalizada en los círculos de la izquierda de aquel entonces, de que todos los que se habían alejado del Partido Comunista (o iban alejándose) eran enemigos del humanismo y la liberación del hombre por el hombre. En 1941 se produce la ruptura entre Paz y Neruda, una ruptura en la superficie por discrepancias en la compilación de la antología Laurel, reveladas posteriormente por Paz en un largo e interesante artículo publicado en Sombras de obras (1983); en el fondo, empero, a causa de insalvables diferencias estéticas y éticas, las que, como se ha demostrado, ya habían nacido años atrás y que ahora salían a la luz. ${ }^{9}$ En aquel momento, Neruda, que ejercía de cónsul general de Chile en México, ya había hecho suyas las directivas del comunismo estalinista, que le marcarán, con diferentes grados de intensidad, por el resto de su vida (se adhiere oficialmente al Partido Comunista de Chile en 1945). Practicaba una versión por personal no menos contundente de la poesía social, de cuyas características Paz iba desmarcándose en favor de una

${ }^{8}$ No descarto la posibilidad de que Paz hubiera visto la Exposición Internacional del Surrealismo, que César Moro y Wolfgang Paalen habían organizado en México en la Galería de Arte Mexicano a principios de 1940, y que su boutade contra el Surrealismo, no desprovista de ingeniosidad, fuera el resultado de una reacción negativa ante los objetos expuestos. Escalante (61 ss.) señala que, con motivo de la exposición, salió un ataque vitriólico de Cardoza y Aragón contra el Surrealismo en el número enerofebrero de 1940 de Taller, cuyo director era, precisamente, Octavio Paz.

${ }^{9}$ Ver el análisis de Stanton 2015: 54 ss. 
concepción de la poesía a igual distancia de la poesía pura y la poesía comprometida.

En 1943, Paz publica en la revista Letras de México un artículo mordaz contra Neruda, quien después de un solemne (y suntuoso) banquete, ofrecido en su honor, iba a dejar el cargo de cónsul en México para volver a Chile. Este artículo, titulado "Respuesta a un cónsul" (y nunca recogido por Paz en ninguna de sus publicaciones posteriores, ni siquiera en las Obras completas) significó la ruptura definitiva e irremediable entre los dos poetas (pese a un fugaz reencuentro de ambos en Londres en 1967, marcado, más bien, por un penoso desconcierto y malestar). ${ }^{10}$ Poco después de la ruptura, Paz salió a Estados Unidos, donde iba a conocer más de cerca la poesía conversacional norteamericana, un acercamiento documentado por las primeras versiones de algunos poemas incluidos en Libertad bajo palabara de 1949 bajo el título de "El joven soldado" (1949: 96-103). Estos poemas (como "Conversación en un bar”, y algunos más) aluden a la dualidad oculta de la realidad, idea cara al pensamiento surrealista, pero todavía no la expresan en su lenguaje onírico.

Lo que sí hacen evidente estos poemas, es la distancia tomada por Paz con respecto a la escritura de Pablo Neruda, tanto del Neruda de Tentativa del hombre infinito y las dos partes de Residencia en la tierra (1931/1935) (también afectadas, como se sabe, por la influencia surrealista) como, antes que nada, del Neruda de la Tercera Residencia (1947), con su tono de combatividad política. Cabe recordar en este contexto que la poesía temprana de Paz estaba fuertemente influida por el lenguaje nerudiano de una poesía sin pureza, como lo evidencian el poemario Raiz del hombre de 1937 y, antes que nada, el poema "El barco", publicado en 1938 en México por la revista Poesía, así como el último número de Hora de España. ${ }^{11}$

${ }^{10}$ Ver Paz 1943: 95.

${ }^{11}$ El texto del poema varía en la disposición de versos y estrofas de una revista a otra (Stanton 2001: 88, n. 63). Vuelve a imprimirse, radicalmente refundido, con el nuevo título de "Los viejos" en Libertad bajo palabra, 1960. La versión definitiva del poema se lee en Paz 2004: 107-109. Las dos versiones de "El barco", a diferencia de otros poemas de juventud, no se recogieron en el vol. VIII de las Obras completas, que reúne los primeros escritos del poeta. En un artículo pionero sobre los inicios de Paz, Klaus Müller-Bergh (130 y ss.) señaló la proximidad de "El barco" con el poema "El 
En el plano estético, la primera versión de Libertad bajo palabra, publicada por Paz en 1949, ya muestra indicios claros del impacto que el Surrealismo iba ejerciendo sobre el autor mexicano. ${ }^{12}$ No obstante, el poemario aún presenta una cierta heterogeneidad que sólo desaparecerá con ¿Águila o sol? (1951), la obra más surrealista del autor. En 1942, Paz había conocido a Benjamin Péret, el compañero de ruta más íntimo de André Breton. Péret y su compañera Remedios Varo se habían refugiado en México a principios de los ańos cuarenta, porque en la Francia de Vichy, Péret corría el riesgo de ser arrestado por su compromiso político de izquierdas y su participación activa en la Guerra Civil española. ${ }^{13}$ Algunos años después, ya de vuelta en París, Péret introduce a Paz al círculo de los surrealistas. A finales de 1945, como se sabe, Paz había obtenido el modesto cargo de secretario en la embajada mexicana en Francia, lo cual le permitía participar en la vida literaria y cultural de la capital francesa de aquel entonces.

A principios de 1947, la revista literaria Fontaine de Max-Pol Fouchet publica en su número 57 dos poemas de Paz en versión original junto con una traducción al francés ("Sueño de Eva" —el que más tarde se llamará "Virgen" — y "Cuarto de hotel"). ${ }^{14}$ En ambos textos — "Cuarto de hotel" muestra además la influencia de los poemas filosófico-morales

fantasma del buque de carga" de Residencia en la tierra, en la edición de Madrid 1935, de Pablo Neruda.

${ }^{12}$ Wilson (1979), a quien se debe el primer estudio que se ocupa detalladamente del impacto del Surrealismo en el autor mexicano, señala una mención hecha en Puertas al campo (Paz 1967: 191) sobre la tela "Europe après la pluie, II" (1940-42) (Europa después de la lluvia, II) de Max Ernst, la que habría sido una de las primeras obras que le abrieron a Paz la vía hacia el Surrealismo (Wilson 1979: 21). Paz debe haber visto esa tela en Nueva York en 1945, probablemente en una exposición de Max Ernst en la Julian Levy Gallery. La tela se encuentra hoy en el Wadsworth Atheneum Museum of Art, Hartford, Connecticut.

${ }^{13}$ Sobre la estancia de Benjamin Péret en México entre 1941 y 1947 informa el estudio de Fabienne Bradu (1998), el que, además, ofrece una recopilación de los textos del autor francés en y sobre México en traducción española.

${ }^{14}$ Fontaine era una revista literaria que Max-Pol Fouchet había fundado en Argel en 1939. Situada en zona libre de Francia durante la ocupación alemana, la revista llegó a ser una importante tribuna para muchos escritores franceses vinculados a la Resistencia como Max Jacob, Henri Michaux y René Char. En 1945, la revista se instala en París, donde sobrevive hasta finales de 1947, ver <https://fr.wikipedia.org/Fontaine_(revue)> [fecha de consulta: 28-X-2015]. En la Biblioteca Nacional de Francia la revista se custodia bajo la signatura $8^{\circ} \mathrm{Z} 28480$. Que yo sepa no existe ningún acceso en línea. 
de Quevedo- existen puntos de contacto con el imaginario del Surrealismo. Estos puntos se señalan por la transgresión de los límites entre realidad y sueño. No se puede descartar, además, la influencia de la poesía de Xavier Villaurrutia, quien en México había creado a través de la temática del sueńo y de la muerte una cierta proximidad con el Surrealismo. Paz conocía personalmente a Villaurrutia y admiraba su poesía. Muchos años después, le va a dedicar un importante ensayo, en el que trata también los puntos de contacto entre Villaurrutia y el Surrealismo (1978b: 58 ss.).

En 1950, el grupo surrealista da a conocer su Almanach surréaliste du demi-siècle (Almanaque surrealista de medio siglo). Paz colabora con un poema en prosa titulado "Papillon d'obsidienne" (Mariposa de obsidiana), en el cual la deidad azteca Itzpapálotl se dirige en un lenguaje onírico, lleno de imágenes extrańas, a un interlocutor no especificado. ${ }^{15}$ El texto vuelve a publicarse en lengua española al ańo siguiente, junto con dos poemas más de Paz, en la revista Orígenes de Lezama Lima y se incluye, asimismo, en la colección ¿Águila o sol?, que publica el Fondo de Cultura Económica con dibujos de Rufino Tamayo. El texto puede tomarse como una concreción de la visión del mundo de antes y después de la Conquista en imágenes de insólita belleza. Promete al final "un reinado dichoso: el pacto de los gemelos enemigos, el agua que escapa entre los dedos y el hielo, petrificado como un rey en su orgullo. Allí abrirás mi cuerpo en dos, para leer las letras de tu destino" (1951: 96). En el texto surge la idea de la reconciliación de los contrarios, la que también se expresa en otras partes de la vasta obra de Paz, y que era una de las visiones más caras al Surrealismo. ${ }^{16}$

En su época parisina, Paz participa aún en otras actividades del grupo surrealista. ${ }^{17}$ Firma algunas de sus declaraciones como "Haute Fré-

${ }^{15}$ Para el texto de Paz, que fue traducido al francés por Martine y Monique Fong, y que lleva la fecha del 6 de enero de 1949, me sirvo de la reimpresión del Almanach surrealiste du demi-siècle. Paris: Ed. Plasma, 1978.

${ }^{16}$ Verani (1995) ofrece un agudo análisis del poema, el que interpreta como expresión de la poética surrealista del autor. Dice Verani al respecto: "En dos páginas, el poema condensa nociones claves de su escritura del medio siglo: la búsqueda de vestigios de la otredad en lo legendario azteca, el encadenamiento de imágenes incongruentes que emanan de estados oníricos, y la supremacía de la comunión erótica para restablecer un equilibrio cósmico, nostalgia utópica que fertiliza toda su obra poética” (433).

${ }^{17}$ Para una lista detallada de las diversas participaciones de Paz en publicaciones y actividades del grupo de los surrealistas véase Wilson 1979: 25 y ss. 
quence" (Alta Frecuencia), de mayo de 1951, la que plantea una reafirmación de las convicciones básicas del Surrealismo frente a una tentativa de un entendimiento, que en los ojos de algunos lo acercaba demasiado a lo religioso en detrimento de lo sagrado (Carrouges), o lo asociaba a un ateísmo a secas, sin considerar la importancia que tenía para el Surrealismo la esfera de lo maravilloso (Pastoureau).$^{18}$ Además, pone su firma bajo la proclama "Contre la répression en Catalogne", publicada con motivo de la represión del movimiento huelguístico en Cataluña en la primavera de 1951. Esta proclama no sólo lleva la firma de los surrealistas, sino también de Simone de Beauvoir, Jean-Paul Sartre, Albert Camus y otros. En el mismo año, Paz publica documentos sobre el trotskista francés David Rousset y los campos de concentración soviéticos, lo que confirma su escandalosa existencia; Rousset los había denunciado en un artículo del Figaro Littéraire. La documentación, publicada en la revista Sur de Victoria Ocampo, le atrae a Paz el odio abierto de gran parte de la izquierda latinoamericana, el que va a persistir hasta más allá de la muerte del autor. Los surrealistas condenaron también la existencia de los campos de concentración en la URss, aunque con la reserva de que no les gustaba (especialmente a Benjamin Péret) el uso que se hacía de las revelaciones de Rousset en las diversas polémicas políticas de la Guerra Fría (Meyer-Minnemann 2002). Finalmente, ya de vuelta en México, Paz contesta un cuestionario acerca del arte mágico, que Breton, quien preparaba un volumen sobre el tema, había enviado a varias personalidades como Martin Heidegger, André Malraux, Julien

${ }^{18}$ Ver la octavilla "Haute Fréquence", en <www.andrebreton.fr/file/298442/ plain?size=full $>$ [fecha de consulta: 29-IX-15]. Michel Carrouges había publicado en 1950 un libro inteligente sobre las ideas fundamentales del Surrealismo (1967), que encontró la aprobación de André Breton. Pero Carrouges, que sólo tangencialmente pertenecía al grupo de los surrealistas, era católico practicante. Sus ideas resultaban, visto el anticlericalismo incondicional del Surrealismo, sospechosas para algunos miembros del grupo. Pastoureau, por su parte, quien había sido el autor principal de la declaración "Rupture Inaugurale", con la que el Surrealismo había manifestado su retorno a la escena parisina después de la Segunda Guerra Mundial — junto con la exposición "Le Surréalisme en 1947” en la galería Maeght - trató de alinear el Surrealismo a una posición atea demasiado racionalista, lo cual molestaba tanto a Breton como a Péret; ver Ducornet: 135 ss. 
Gracq, Georges Bataille, Claude Lévi-Strauss y otros. ${ }^{19}$ La respuesta de Paz se inserta en Las peras del olmo inmediatamente después del ensayo sobre el Surrealismo (1957: 182-190). Puede leerse como un complemento de las observaciones del autor sobre el Surrealismo hechas en su ensayo de 1954/1957. ${ }^{20}$

La adhesión de Paz al Surrealismo alrededor de 1950 no se da, empero, sin algunas reservas. Una de éstas se refiere a la figura del marqués de Sade, quien por más que fuera admirado por los surrealistas — lo habían erigido en "emblema de rebeldía" (Paz 1993: 69) - tampoco era un personaje completamente incontrovertido entre ellos. En Libertad bajo palabra (1949), Paz incluye un poema de 1948 titulado "El prisionero (Homenaje a D.A.F. de Sade)", dedicado al "divino marqués". ${ }^{21}$ Si bien es cierto que ahí Paz celebra a Sade, le señala también un grave defecto. El título del poema juega con una ambigüedad. Por una parte alude a los largos años de encarcelamiento que Sade padeció; por otra, apunta hacia el solipsismo del marqués, incapaz en sus fantasías de transgresión erótica de percibir al otro como sujeto. La estrofa más famosa del poema reza:

Prisionero en tu castillo de cristal de roca cruzas galerías, cámaras, mazmorras, vastos patios donde la vid se enrosca a columnas solares, graciosos cementerios donde danzan los chopos inmóviles. Muros, objetos, cuerpos te repiten.

¡Todo es espejo!

Tu imagen te persigue (1949: 19). ${ }^{22}$

${ }^{19}$ El volumen se publica con el título de L’Art Magique en 1957 bajo el sello del "Club français du livre"; ver Breton 2008. El interés de Breton por la magia, entendida como una forma particular de pensamiento, percepción e interacción entre el mundo de los fenómenos y su aprehensión más allá de un entendimiento racionalista, se había intensificado durante el exilio americano del autor. Un estudio detallado de los orígenes de ese interés y su evolución en el marco de los postulados del Surrealismo se encuentra en la excelente investigación de Bauduin (2014).

${ }^{20}$ Una interpretación profunda de la respuesta de Paz al cuestionario del autor francés se ofrece en Nicholson 2013: 212 ss.

${ }^{21}$ Para lo que sigue respecto de este poema de Paz véase también el análisis de Wilson 1979: 34-43.

${ }^{22}$ Cito el texto del poema según la primera versión; la recogida en Paz 2004: 126128 es un tanto diferente, más sutil, probablemente, y más coherente, menos retórica. 
En su ensayo sobre André Breton, publicado como homenaje con motivo de la muerte del autor francés, ocurrida en 1966, Paz dice respecto de la admiración de Breton por el marqués de Sade:

Es difícil entender del todo su adhesión sin reservas hacia la obra de Sade. Cierto, lo conmovía y exaltaba el carácter absoluto de su negación, pero ¿̇cómo conciliarla con la creencia en el amor, centro de la edad de oro? Sade denuncia el amor: es una hipocresía, o, peor aún, una ilusión. Su sistema es delirante, no incoherente: su negación no es menos total que la afirmación de San Agustín. Ambos repudian con idéntica violencia todo maniqueísmo; para el santo cristiano el mal no tiene realidad ontológica; para Sade lo que carece de realidad es lo que llamamos bien: su versión del Contrato social son los estatutos de la Sociedad de Amigos del Crimen (2000b: 198).

En el ensayo "Cárceles de la razón", de 1986, incluido más tarde en Un más allá erótico: Sade, de 1993, Paz se pregunta ante el levantamiento de la larga prohibición de leer y publicar las obras del marqués:

¿Sade se volverá un autor inocuo? No lo sé. Tampoco sé lo que quedará de esa obra inmensa y monótona. Tal vez una ruina, melancólica como todas las ruinas, hecha no de un montón de piedras rotas sino de miles y miles de páginas en las que se despliega, incansable, a través de laboriosas invenciones e incontables repeticiones, un delirio frío y razonante (1993: 72).

Cuando Paz escribe su poema sobre Sade, la memoria del marqués estaba, por decirlo así, en el aire parisino. No sólo los surrealistas, sino también intelectuales como Jean Paulhan o Pierre Klossowski (su libro controvertido Sade, mon prochain, es de 1947) se habían ocupado de él. En el catálogo de la exposición Le Surréalisme en 1947 se incluye un ensayo de Maurice Nadeau sobre el marqués, titulado "Sade, ou l'insurrection permanente" (Sade o la insurrección permanente) (Nadeau 1947), que Paz, probablemente, haya leído, como leyó a Paulhan y a Klossowski (Paz 1993: 73). ${ }^{23}$ Nadeau, cuya historia del Surrealismo

${ }^{23}$ En una entrevista con Anthony Stanton, Paz recuerda, en relación con sus primeras lecturas de Sade, el estudio de Jean Paulhan, que éste antepuso a una edición de la Justine (2003: 114). No he podido ver esta edición, que salió en 1946 en París bajo el sello de "Les Éditions du Point du Jour". Su título correcto, ya que se trataba de la pri- 
se había publicado dos años antes, ve en Sade a un materialista ateo, en permanente insurrección contra la sociedad, el tiempo y la historia, pero al mismo tiempo creador de un universo cerrado, falto de comunicación. ${ }^{24}$

Otra de las reservas de Paz frente al Surrealismo se refiere a la escritura automática y sus aspiraciones. En el ya mencionado ensayo necrológico dedicado a Breton, Paz destaca cómo la práctica de la escritura automática significaba para el autor francés la esperanza de obtener un acceso directo al lenguaje primordial, más allá del uso determinado por el filtro de la conciencia, filtro impuesto tanto por la premeditación en el acto locutivo como por los imperativos enajenantes de la vida social. En su libro ya mencionado sobre las ideas fundamentales del Surrealismo, Michel Carrouges había señalado que detrás del dictado de la escritura automática no existía ninguna instancia directora autónoma identificable, sino que sólo se trataba de una función del espíritu humano en acción, la que hacía emerger los estratos verbales del subconsciente (183).

En su ensayo de 1954/1957 sobre el Surrealismo, Paz califica la escritura automática como "la más notable y eficaz" técnica de la "sistemática destrucción del yo —o mejor dicho: la objetivización del sujeto"entre las empleadas por los surrealistas. No obstante, al mismo tiempo agrega: "Método experimental, temo que la escitura automática pocas veces se haya realizado de verdad" (1957: 170 y ss.). Posteriormente,

mera versión de esta novela de Sade, de 1787, reza: "Les infortunes de la vertu. Avec une notice de Maurice Heine, une bibliographie de Robert Valençay et une introduction par Jean Paulhan". En el ya mencionado ensayo "Cárceles de la razón", Paz comenta con cierta reserva el estudio de Paulhan, cuya conclusión paradójica consiste en ver en las fantasías de transgresión sexual sufridas por Justine una expresión del masoquismo del mismo Sade (1993: 73 ss.). Es probable que tanto la lectura de Justine, en la edición de 1946, como la del estudio de Paulhan, le dieran el impulso para escribir el poema sobre Sade, publicado en Libertad bajo palabra (1949). El estudio de Paulhan puede leerse en Paulhan 1969.

${ }^{24}$ Alquié, por lo general comprensivo hacia el ideario del Surrealismo, advierte que los surrealistas nunca llegaron a aclarar bien su actitud ante la figura y la obra del marqués de Sade, a pesar de su admiración por la actitud de rebeldía de este último ante la vida, las condiciones mismas de la existencia y todo lo que ponga trabas al deseo y el amor (78). En este sentido, la crítica de Paz hacia el solipsismo de Sade puede interpretarse como una concreción de un cierto malestar (no abiertamente confesado) del Surrealismo (o de algunos de sus miembros) hacia la persona y la obra del "divino marqués". 
Paz matiza su juicio. Ahora ya no considera la escritura automática un método experimental para llegar a un estado de perfecta espontaneidad e inocencia, sino la ve más bien como una meta que, si fuese realizable, sería ese estado de inocencia, en el que "hablar, sońar, pensar y obrar" se volverían lo mismo. Pero ese estado, en el fondo considerado como inalcanzable, excluiría toda escritura. "¿A qué escribir?", se pregunta Paz, y ańade: "El estado a que aspira la 'escritura automática' excluye toda escritura" (2000a: 178).

Está claro que para el mexicano la práctica de la escritura automática (y aún más su meta) llevaría a la negación completa del yo como instancia inconfundible del decir poético y la expresión de una voz única e irrepetible. Parece que no se conformaba con la idea de esa negación en la actividad poética, aunque mantuviera la convicción de la dualidad esencial entre el yo y su otro expresada en el poema. La idea de una manifestación del yo, en la cual éste y su otro no sólo son el objeto de la expresión, sino, al mismo tiempo, las instancias que se expresan, como lo había planteado el Romanticismo, era una de las convicciones fundamentales de Paz. En la primera versión de El arco y la lira (1956), la que se publica casi al mismo tiempo que el ensayo sobre el Surrealismo de Las peras del olmo, Paz afirma el carácter personal de la palabra poética, que es, a la vez, tanto "cifra del instante de la creación" (1956: 175) como expresión histórica. ${ }^{25}$ Ya la palabra "creación" frente a la idea del fluir inconsciente de la palabra en la práctica de la escritura automática revela la actitud de distanciamiento hacia esta última por parte del autor. Al respecto, Anthony Stanton advierte que la concepción psicológica de Breton (influida por Freud) de la inspiración poética se ve modificada en el El arco y la lira por "una concepción ontológica de la temporalidad dentro de una estética romántica de la reintegración a los orígenes", inspirada por la filosofía de Heidegger y por Antonio Machado (2015: 408). Es antes que nada la filosofía del Heidegger de Sein und Zeit, en la versión de José Gaos (El ser y el tiempo), la que, como afirma Evodio Escalante (34 ss.), resulta decisiva para Paz en su entendimineto de la actividad poética.

No obstante, queda aún por determinar la inspiración poética, si ésta no puede identificarse con el dictado del inconsciente mediante

${ }^{25}$ La segunda edición, corregida y aumentada, de El arco y la lira, de 1967, recoge íntegra esta importante aseveración acerca de la poética del autor; ver Paz 1970b: 179. 
el procedimiento de la escritura automática. Paz trata de resolver ese problema definiendo la inspiración no como una fuerza oculta, a la cual es preciso entregarse, sino como una aspiración, que se manifiesta como ejercicio de una actividad dirigida hacia sí misma. En palabras del autor:

La inspiración es una manifestación de la "otredad" constitutiva del hombre. No está adentro, en nuestro interior, ni atrás, como algo que de pronto surgiera del limo del pasado, sino que está, por decirlo así, adelante: es algo (o mejor: alguien) que nos llama a ser nosotros mismos. $\mathrm{Y}$ ese alguien es nuestro ser mismo. Y en verdad la inspiración no está en ninguna parte, simplemente no está, ni es algo. Es una aspiración, un ir, un movimiento hacia adelante, hacia eso que somos nosotros mismos (1956: 175). ${ }^{26}$

Está claro que puesto así, la inspiración no puede ser una potencialidad ubicada en el inconsciente, de difícil o imposible alcance por lo demás, sino una actividad orientada hacia la apropiación de la palabra en el sentido de una revelación de lo originario. En efecto, esta apropiación, que a veces, como en "Trabajos forzados" de ¿Águila o sol? (1951), puede ser, incluso, violenta, representa el núcleo de la inspiración. No se manifiesta en una actitud de inercia, sino que presupone, en palabras de Paz, una "pre-meditación" (1956: 170 ss.) —esta última, como señala Escalante (2013: 38), un neologismo, calcado sobre los usos lingüísticos de Heidegger- la que lleva a un estado psíquico entre dejar brotar la palabra y atraparla en un acto de trascendencia de sí mismo hacia el verdadero Ser. En este sentido, como advierte Escalante (42 ss.), Paz va más allá de la filosofía del Dasein, esto es, del ser-en-el-mundo del Heidegger de Sein und Zeit, pero, como al mismo tiempo se puede añadir, no de las aspiraciones fundamentales del Surrealismo de un cambio de la vida (Rimbaud) por medio de la poesía.

Ahora bien, ya el mismo Breton había manifestado algunas dudas respecto de la eficacia y practicabilidad del automatismo en un importante ensayo publicado en $1933 .{ }^{27}$ Parece además que después de la

${ }^{26}$ También este pasaje pasó sin cambios a la segunda edición de El arco y la lira (1970b: 179).

${ }^{27}$ El ensayo titulado "Le message automatique" (El mensaje automático) fue incluido en Point du jour (1934); ver Breton 1992a: 375-392. 
Segunda Guerra Mundial el autor francés (y con él el Surrealismo en general) habían perdido la fe en la posibilidad de realizar plenamente los postulados de cambio de la vida a través de las prácticas surrealistas, o, más difícil aún, de aunarlas con la militancia política y social en un contexto más amplio (Vogt: 140 ss.). Para Paz la actividad poética y su resultado, el poema, eran, por cierto, la manifestación del yo y su otro en la sociedad moderna y, de ahí, la expresión de su crítica radical, pero no eran capaces de asegurar la transformación del mundo (Marx) y el cambio de la vida (Rimbaud). Con el tiempo, además, Paz parece haber puesto en tela de juicio las condiciones de posibilidad de esa transformación y de ese cambio. De todos modos, ya no los reclamaba explícitamente. La creciente condena del estalinismo y de las sociedades fundadas por (y en) él, una condena que, finalmente, también afectaba los fundamentos teleológicos del marxismo, llevaron al autor mexicano, a pesar de la crítica persistente del poder destructivo de las sociedades occidentales, a una afirmación de su forma de organización política, esto es, de la democracia liberal, la que no preveía ningún sitio para una concepción diferente de la existencia humana como la que anhelaba el Surrealismo. Lo que no cambiaba en el ideario de Paz (por lo menos en principio) era la actitud de rebeldía, la que oponía a la sociedad juzgada como restrictiva la experiencia solitaria (y anárquica, como podemos agregar) de la libertad, el amor y la poesía.

En 1957, Paz publica el poema largo "Piedra de Sol". Este poema, basado en el significado simbólico del planeta Venus, es un himno al amor como fuerza rebelde en contra de la vida esterilizante de la sociedad. Los vínculos que entabla con el Surrealismo son numerosos (Wilson 2007). Sin embargo, el poema está escrito en 589 endecasílabos blancos, de los que los últimos cinco, así como el pentasílabo final, repiten, en un gesto de circularidad, los seis primeros. El endecasílabo, por su forma (para no decir por su fórmula: un verso de once sílabas con posibilidades variadas de ritmo, con la salvedad de la décima sílaba que obligatoriamente recibe el acento de intensidad) representa una expresión lingüística que apenas podría estar más lejos de la libertad de la escritura automática. No obstante, el endecasílabo blanco y a-estrófico empleado en "Piedra de Sol" comparte con esta última un movimiento de fluir. Es interesante observar cómo en "Blanco", el siguiente poema largo de Paz, publicado en 1967, el poeta des-construye ese fluir en beneficio de una tendencia hacia la inmovilización conforme a las carac- 
terísticas de la poesía visual. El resultado de esta inmovilización consiste en la suspensión del flujo del discurso poético a favor de un prevalecer del "estar ahí" de la palabra. "Blanco", que se propone dialogar con la poética de "Un Coup de Dés" (Un golpe de dados) de Mallarmé, muestra un parentesco bastante estrecho con la escritura de la Poesía Concreta brasileña, por la que Paz se interesó en los años sesenta. Con este interés, el autor se alejó por un algún tiempo de la orientación surrealista, la que había caracterizado su obra en los años anteriores. ${ }^{28}$

"Blanco" fue incluido en el poemario Ladera este (1969), que reúne los poemas de Paz escritos bajo el impacto de las experiencias culturales que el poeta había vivido como embajador de México en la India. En medio de ese cuerpo poético se halla un grupo de cuatro poemas titulado "Intermitencias del Oeste", de los cuales el tercero ("México: Olimpiada de 1968") alude a la matanza de Tlatelolco del 2 de octubre de 1968 (Paz 1970a: 68 y ss.), a raíz de la cual el autor, en señal de protesta, renunció a su puesto de embajador. Sobre esta renuncia - Paz fue el único alto funcionario mexicano que dejó su puesto en protesta contra la represión - se ha escrito mucho, no siempre con la serenidad apropiada. No voy a agregar otro comentario más, con la salvedad, sin embargo, de que la renuncia de Paz se hizo también en plena concordancia con los criterios morales del Surrealismo.

Las intermitencias de Ladera este recogen un procedimiento que Paz conocía del poema "Nocturno alterno" de José Juan Tablada, de 1920, al que admiraba. Este procedimiento consiste en la yuxtaposición de dos realidades distintas (imaginarias o no), las que por las normas lingüísticas y culturales del lenguaje normalmente no se juntan. Aunque no sea propiamente de raigambre surrealista (era un hallazgo de Pierre Reverdy, de cuya existencia Tablada, tal vez, se había percatado cuando vivía como exiliado en Nueva York), el procedimiento fue empleado con frecuencia por los miembros del grupo de Breton como uno de los medios más seguros del acceso a lo sobrenatural. En Salamandra (1962), poemario de Paz inmediatamente anterior a Ladera este, hay un poema titulado "José Juan Tablada", donde el poeta se sirve de ese procedimiento, haciendo alternar versos de Tablada con versos propios. El poemario aún muestra otras afinidades con el Surrealismo que habría

${ }^{28}$ Ver en cuanto a la aproximación (en parte crítica) de Paz a la poesía concreta brasileña, el artículo esclarecedor de Antonio Ochoa 2003-2005. 
que detallar en otra ocasión. Un testimonio de la admiración persistente de Paz por el Surrealismo (para no decir de su fascinación) es el poema "Esto y esto y esto", incluido en Árbol adentro (1987: 54 y ss.), del cual el poeta publicó una primera versión (apenas diferente) al principio de su reseña de la Antología de la poesía surrealista latinoamericana de Stefan Baciu en la revista Plural, 35, agosto de 1974, recogida unos años después en la colección de ensayos y notas titulada In/Mediaciones (1979: 153 y ss.).

\section{BiBLIOGRAFÍA}

Alquilé, Ferdinand. Philosophie du surréalisme. Paris: Flammarion, 1955.

Bauduin, Tessel M. Surrealism and the Occult. Occultism and Western Esotericism in the Work and Movement of Andre Breton. Amsterdam: Amsterdam University Press, 2014.

Bradu, Fabienne. Benjamin Péret y México. México: Editorial Aldus, 1998.

Breton, André. "Le message automatique", en CEuvres complètes, vol. II. Édition établi par Marguerite Bonnet. Bibliothèque de la Pléiade. Paris: Gallimard, 1992a: 375-392.

Breton, André. "Discours au Congrès des Écrivains", en CEuvres complètes, vol. II. Édition établi par Marguerite Bonnet. Bibliothèque de la Pléiade. Paris: Gallimard, 1992b: 451-459.

BRETON, ANDRÉ. Arcane 17 enté d'ajours. Textes établis, présentés et annotés par Étienne-Alain Hubert, en CEuvres complètes, vol. III. Édition de Marguerite Bonnet. Bibliothèque de la Pléiade. Paris: Gallimard, 1999: 35-113.

Breton, André. L'Art Magique, en Écrits sur l'art et autres textes. Euvres complètes, vol. IV. Édition de Marguerite Bonnet. Publiée, pour ce volume, sous la direction d'Étienne-Alain Hubert avec la collaboration de Philippe Bernier et Marie-Claire Dumas. Bibliothèque de la Pléiade. Paris: Gallimard 2008: 47-289.

Bürger, Peter. Der französische Surrealismus. Studien zur avantgardistischen Literatur. Um neue Studien erweiterte Ausgabe. Frankfurt am Main: Suhrkamp, 1996.

Bürger, Peter. Teoría de la vanguardia. Traducción Tomás Joaquín Bartoletti. Buenos Aires: Ed. Las cuarenta, 2009.

Carrouges, Michel. André Breton et les données fondamentales du Surréalisme. Paris: Gallimard, 1967.

Contat, Michel y Michel Rybalka. Les écrits de Sartre: chronologie, bibliographie commentée. Paris: Gallimard, 1970. 
Ducornet, Guy. Surréalisme \& Athéisme. "À la niche les glapisseurs de dieu”. Paris: Gingko éditeur, 2007.

Escalante, Evodio. Las sendas perdidas de Octavio Paz. México: Universidad Autónoma Metropolitana (Unidad Iztapalapa) / Ediciones Sin Nombre, 2013.

Meyer-Minnemann, Klaus. “Octavio Paz, David Rousset y el universo de los campos de concentración”, en Literatura Mexicana 13 (2002): 151172.

Müller-Bergh, Klaus. "La poesía de Octavio Paz en los años treinta", en Revista Iberoamericana 74 (1971): 117-131.

Nadeau, Maurice. "Sade, ou l'insurgence permanente", en Le Surréalisme en 1947 (Exposition Internationale du Surréalisme. Présentée par André Breton et Marcel Duchamp). Paris: Maeght éditeur, 1947: 35-41.

Nicholson, Melanie. Surrealism in Latin American Literature. Searching for Breton's Ghost. New York: Palgrave Macmillan, 2013.

Ochoa, Antonio. "Palabras en un mundo de objetos", en Zunái. Revista de poesia \& debates I (2003-2005), artículo en línea disponible en <www. revistazunai.com/ensaios/antonio_ochoa.htm>.

Paulhan, Jean. "Le marquis de Sade et sa complice, ou Les revanches de la pudeur", en Euvres complètes de Jean Paulhan, t. IV. Paris: Cercle du Livre Précieux, 1969: 9-36.

Paz, Octavio. "El barco", en Poesía: mensual de literatura 3 (1938): 15-18 [Reimpreso 1981, y con variantes en Hora de España 23 (1938): 4345].

Paz, Octavio. "Respuesta a un cónsul”, en Letras de México VII, num. 8 (15 de agosto de 1943): 95.

Paz, Octavio. Libertad bajo palabra. México: Fondo de Cultura Económica, 1949 (Tezontle).

Paz, Octavio. ¿Águila o sol? México: Fondo de Cultura Económica, 1951 (Tezontle).

Paz, Octavio. El arco y la lira. El poema. La revelación poética. Poesía e historia. México: Fondo de Cultura Económica, 1956.

Paz, Octavio. Las peras del olmo. México: Universidad Nacional Autónoma de México, 1957.

Paz, Octavio. Poesía en movimiento. México, 1915-1966. Selección y notas de O.P., Alí Chumacero, José Emilio Pacheco y Homero Aridjis. Prólogo de O.P. México: Siglo XXI Editores, 1966.

Paz, Octavio. Puertas al campo. Segunda edición. México: Universidad Nacional Autónoma de México, 1967.

Paz, Octavio. Ladera este (1962-1968). Segunda edición. México: Joaquín Mortiz, 1970a. 
Paz, Octavio. El arco y la lira. El poema. La revelación poética. Poesía e historia. Segunda edición corregida y aumentada. Primera reimpresión. México: Fondo de Cultura Económica, 1970b.

Paz, Octavio. "Poesía en movimiento", en Poesía en movimiento. México, 1915-1966. Selección y notas de O.P., Alí Chumacero, José Emilio Pacheco y Homero Aridjis. Prólogo de O.P. México: Siglo XXI Editores, 7a. edición, 1973: 3-34.

Paz, Octavio. "Papillon d'obsidienne", en Almanach surréaliste du demi-siécle. Numéro special de La Nef. Paris: Éditions Plasma, 1978a: 29-31.

Paz, Octavio. Xavier Villaurrutia en persona y en obra (Con 10 dibujos de Juan Soriano y una Iconografía). México: Fondo de Cultura Económica, 1978 b.

Paz, Octavio. In/Mediaciones. Barcelona: Seix Barral, 1979.

Paz, Octavio. "Poesía e historia" (Laurel y nosotros), en Sombras de obras. Arte y literatura. Barcelona: Seix Barral, 1983: 47-93.

Paz, Octavio. Árbol adentro. Barcelona: Seix Barral, 1987.

Paz, Octavio. Primeras letras (1931-1943). Selección, introducción y notas de Enrico Mario Santí. Barcelona: Seix Barral, 1988.

Paz, Octavio. Los hijos del limo. Del romanticismo a la vanguardia. Segunda edición en Biblioteca de Bolsillo. Barcelona: Seix Barral, 1989.

Paz, Octavio. Un más allá erótico: Sade. México: Ed. Vuelta / Ed. Heliópolis, 1993.

Paz, Octavio. "Estrella de tres puntas: el surrealismo", en Obras completas, vol. II. Excursiones/Incursiones (Dominio extranjero). Fundación y disidencia (Dominio hispánico). Edición del autor. Segunda edición. Barcelona: Galaxia Gutenberg / Círculo de Lectores, 2000a: 171-187.

Paz, Octavio. "André Breton o la búsqueda del comienzo", en Obras completas, vol. II. Excursiones/Incursiones (Dominio extranjero). Fundación $y$ disidencia (Dominio hispánco). Edición del autor. Segunda edición. Barcelona: Galaxia Gutenberg / Círculo de Lectores, 2000b: 187200.

Paz, Octavio. "André Breton: la niebla y el relámpago", en Obras completas, vol. II. Excursiones/Incursiones (Dominio extranjero). Fundación y disidencia (Dominio hispánco). Edición del autor. Segunda edición. Barcelona: Galaxia Gutenberg / Círculo de Lectores, 2000c: 231-218.

Paz, Octavio. "Genealogía de un libro: Libertad bajo palabra. Anthony Stanton”, en Obras completas, 15. Miscelánea III. Entrevistas. México: Fondo de Cultura Económica, 2003: 106-121.

Paz, Octavio. Obra poética (1935-1998), en Obras completas, vol. VII. Edición del autor. Segunda edición. Barcelona: Galaxia Gutenberg / Círculo de Lectores, 2004. 
Paz, Octavio. "Respuesta a una encuesta de Romance", en Obras completas, vol. VIII. Miscelánea. Edición del autor. Segunda edición. Barcelona: Galaxia Gutenberg / Círculo de Lectores, 2005: 213-216.

Sartre, Jean-Paul. Situations, II. Qu'est-ce que la littérature. Paris: Gallimard 1968.

Stanton, Anthony. Las primeras voces del poeta Octavio Paz (1931-1938). México: Ediciones Sin Nombre / Conaculta, 2001.

Stanton, Anthony. El río reflexivo. Poesía y ensayo en Octavio Paz (19311958). México: El Colegio de México / Fondo de Cultura Económica, 2015.

Verani, Hugo J. "Mariposa de obsidiana: una poética surrealista de Octavio Paz”, en Literatura Mexicana 5 (1994): 429-442.

Vernengo, Roberto. "Una entrevista con Octavio Paz”, en Octavio Paz. Obras completas, vol. VIII. Miscelánea. Edición del autor. Segunda edición. Barcelona: Galaxia Gutenberg / Círculo de Lectores, 2005: 595-600.

Vital, Alberto. "La nociones de 'tradición' y 'ruptura' como conceptos histórico-literarios", en Literatura Mexicana 9 (1998): 419-126.

Vogt, Ulrich. Le point noir. Politik und Mythos bei André Breton. Frankfurt am Main-Bern, 1982.

Wilson, Jason. Octavio Paz. A study of his poetics. Cambridge: Cambridge University Press, 1979.

Wilson, Jason. "Piedra de Sol", en Hugo J. Verani (ed.). Lecturas de Piedra de Sol. Edición conmemorativa del poema de Octavio Paz. México: Fondo de Cultura Económica, 2007: 92-105. 